\title{
BALKANLARDA YABANCI TERÖRİST SAVAŞÇILAR
}

\author{
Pınar Begüm KIZILGÜL*
}

$\ddot{O} z$

\begin{abstract}
Bu çalışmada Suriye Iç Savaşının başlamasıyla popülerliğini arttıran 'yabancı terörist savaşçı' kavramı incelenmiştir. 18. Yüzylldan itibaren dünyanın pek çok yerinde meydana gelen etnik veya din kökenli çatışmalarda 'yabancı terörist savaşçı' örneklerine rastlanmıştır. Fakat literatürde ortak bir 'terörizm' tanımı olmamasının doğal bir sonucu olarak yabancı terörist savaşçı kavramının da küresel bir tanımı yapılamamaktadır. Bu noktada Birleşmiş Milletlerin almış olduğu iki önemli karar mevcuttur ve bu kararlar doğrultusunda üye devletler yabancı terörist savaşçı kavramını büyük oranda şekillendirmektedir. Yabancı terörist savaşçıların coğrafi dağılımına bakıldı̆̆ında Balkan devletlerinden Suriye'ye ve Irak'a giden kişi sayısı diğer ülkelere nazaran daha azdır. Fakat bölgeye giden kişi sayısının zaman ilerledikçe artması Balkan devletleri için bir süre sonra endişe verici olmuştur. Giden kişiler büyük oranda DEAŞ, El-Nusra Cephesi gibi selefi terör örgütlerine katılım göstermiştir. Tahmin edilen rakamlar içinde Bosna Hersek ve Kosova diğer Balkan ülkelerine nazaran daha fazla orana sahip olan devletler olmuştur. Bu hususlar doğrultusunda makalede Balkan ülkelerinden Suriye'ye veya Irak'a giden kişilerin yaş, cinsiyet, eğitim durumlarl, motivasyon kaynakları ve menşe ülkelerinin yapmış oldukları hukuksal değişikliklere değinilerek yabancı terörist savaşçı kavramı açılklanmaya çalışılacaktır.
\end{abstract}

Anahtar Kelimeler: Yabancı Savaşçılar, Yabancı Terörist Savaşçılar, Balkanlar, Suriye İç Savaşı, $D E A S ̧$, Terörizm

\section{FOREIGN TERRORIST FIGHTERS IN BALKANS}

\begin{abstract}
In this study, the concept of "foreign terrorist fighter" which increased its popularity with the start of the Syrian Civil War was examined. Examples of foreign terrorist fighters have been encountered in ethnic or religious conflicts that have taken place in many parts of the world since the 18th century. However, as a natural result of the lack of a common definition of 'terrorism' in the literature, a global definition of the concept of foreign terrorist fighter cannot be made. At this juncture, there are two important decisions taken by the UN, and regarding these decisions, members states largely shape the FTF concept. Considering the geographical distribution of foreign terrorist fighters, the number of people traveling from the Balkan states to Syria and Iraq is less compared to other countries. But the increase in the number of people going to the region as time passed has been alarming Balkan states after a while. Those people going to the region have largely participated in salafist terrorist organizations such as DEASH, Al-Nusra Front. Among the estimated figures, Bosnia and Herzegovina and Kosovo were the states with a greater proportion than other Balkan countries. In line with these matters, the article will try to explain the concept of foreign terrorist fighters by referring to the age, gender, educational status, motivation sources and legal changes made by the countries of origin from Balkan countries to Syria or Iraq.
\end{abstract}

Keywords: Foreign Fighters, Foreign Terrorist Fighters, Balkans, Syrian Civil War, DEASH, Terrorism

\footnotetext{
* Yüksek Lisans Öğrencisi, Jandarma ve Sahil Güvenlik Akademisi, Güvenlik Bilimleri Enstitüsü Türkiye, pnrbgm01 @ hotmail.com, ORCID: https://orcid.org/0000-0003-0756-9454
} 


\section{GíRiş}

2011 yılında Suriye İç Savaşının başlaması ve siyasi istikrarsızlıktan yararlanan terör örgütlerinin etkinliklerini arttırmasıyla bölgeye gelen terörist sayısı da artmaya başlamıştır. Suriye'ye ve Irak'a farklı ülkelerden gelen teröristlerin artması zamanla hem medyanın hem de ilgili devletlerin dikkatini çekmiştir. Haberlerde, makalelerde sıklıkla 'yabancı savaşçı' veya 'yabancı terörist savaşçı' (YTS) kavramlarına rastlanılmıştır. Birleşmiş Milletler, 2014 yılında yabancı terörist savaşçıları tanımlamaya yönelik iki karar çıkarmış, Cenova Akademisi kendine özgü tanımlamasını yapmış ve pek çok akademisyen araştırmaları doğrultusunda belirli kriterler ortaya koymuştur. Bunlar incelendiğinde görülmektedir ki yabancı terörist savaşçı kavramında ön plana çıkan iki kriter vardır. Vatandaşlık bağı ile bağlı olmadığı bir devletin topraklarındaki çatışmaya katılmış olmaları ve herhangi bir maddi çıkar gütmeden ideolojik nedenlerle bölgeye gelmiş olmaları kişilerin yabancı terörist savaşçı olarak adlandırmasında ön plana çıkan kriterlerdir.

Tarihsel olarak bakıldığında yeni bir kavram olarak düşünülen 'yabancı terörist savaşçı' kavramının kökeni oldukça eskidir. Amerikan Devrimi (1765-1783) bilinen en eski örneklerinden biri olup Yunan İsyanı (1821-1832), Teksas Devrimi (18351836) ve İspanya İç Savaşı (1936-1939) da diğer ciddi örneklerindendir. Bu örneklerde yabancı terörist savaşçı kavramı Hristiyanlık veya Komünistlik üzerinden şekillense de 1979 yılında Sovyetler Birliği’nin Afganistan'ı işgali ile Müslümanlık, İslamiyet kavramları da yabancı terörist savaşçı kavramının kapsamına dahil olmuştur. Bosna Hersek Savaşı, Çeçenistan Savaşı, Somali'de yaşanan çatışmalar ve en güncel örnek olan Suriye İç Savaşıyla da farklı kişiler yeni oluşan cihat alanlarına katılmışlardır. Bu örnekler YTS kavramının tarihsel olarak yeni olmadığı gibi, tek bir örgüte de özgü olmadığını göstermektedir.

Balkan ülkelerinin vatandaşlarının radikalleşme nedenlerinde, Selefilik inancı önemli bir yer tutmaktadır. Selefi örgütler olan DEAŞ (Devlet'ül Irak ve'ş Şam) ve El-Nusra Cephesi (Cephetu'l-Nusra) gibi örgütlere bu sebeple daha fazla katılım olmuştur. Balkan ülkelerinin ekonomilerinin çok parlak olmaması, işsizlik oranlarının yüksek olması ve yeterli siyasi katılımın olmaması da radikalleşme için ortam oluşturmaktadır. Tüm bu sebeplerin etrafında şekillenen radikalleşme süreçleri örgütlerin de militan kazanmalarını kolaylaştırmaktadır. Bu hususlar çerçevesinde makalede, DEAŞ ve El-Nusra Cephesine Bosna Hersek, Kosova, Arnavutluk, Makedonya, Sırbistan ve Karadağ ülkelerinden katılan yabancı terörist savaşçlar incelenmiştir. Yabancı terörist savaşçı kavramına yönelik tartışmalara yer verilmiş ve Balkan devletlerinden bu terör örgütlerine katılan kişilerin yaş, cinsiyet, eğitim durumu gibi faktörlerinin ne olduğu, Balkan devletlerinin vatandaşlarının radikalleşme süreçlerine yönelik ne tür hukuksal tedbirler aldığı açıklanmaya çalışılmıştır. 


\section{YABANCI TERÖRIST SAVAŞÇI KAVRAMI}

'Yabancı terörist savaş̧̧' kavramı son zamanlarda politik söylemlere fazlaca yansımasıyla birlikte medyanın da popüler bir konusu haline gelmiştir. Aslında ortaya çıkışını oldukça eskilere götürmenin mümkün olduğu bu kavram, Suriye İç Savaşıyla birlikte uluslararası gündemde etkinliğini tekrardan hissettirmeye başlamıştır. Vekalet savaşlarının artması, etnik ve dini çeşitliliğin yüksek olduğu yerlerde yaşanan yoğun çatışmalar, terör örgütlerinin etkinlik alanlarını genişletmesi, siyasi istikrarsızlıkların artması gibi nedenlerden dolayı yabancı terörist savaşçı kavramı dünyanın pek çok yerinde dikkatleri üzerine çekmiştir. Bu konuda en güncel örnek Suriye İç Savaşı olmasına karşın Afganistan'ın işgali, Bosna-Hersek savaşı, Kosova savaşı, Somali'de yaşanan çatışmalar, Çeçenistan'da meydana gelen karışıklık ve Irak'ta yaşanan olaylarda da yabancı terörist savaşçı kavramının örneklerine rastlanmıştır.

Yabancı terörist savaşçı kavramının son zamanlarda yaygın olarak kullanılmasıyla birlikte ortaya 'tanımlama' sorunu çıkmıştır. Ortak bir tanım olmamasından dolayı kavram kargaşası yaşanmaktadır. Birleşmiş Milletler Güvenlik Konseyi (BMGK)'nın bu konuda almış olduğu 2170 ve 2178 sayılı iki kararı mevcuttur. 2170 sayılı kararında ilk defa yabancı terörist savaşçılardan bahseden BMGK, kararında yabancı terörist savaşçıları 'sivillerin ölümüne yol açmaya yönelik suç eylemlerini yapanlar ve istikrarı büyük ölçüde baltalayan kişilerden Irak İslam Devleti, El-Nusra Cephesi ve El-Kaide ile ilişkili olanlar' şeklinde tanımlamıştır (Security Council Resolutions, 18.03.2019). Bu karar büyük oranda 'yabancı terörist savaşçıları' tanımlamış fakat yapılan tanım özelde DEAŞ, El-Kaide ve El-Nusra Cephesi gibi cihatçı örgütleri kapsamış ve onlara destek olan kişileri ifade etmek için kullanılmıştır. 24 Eylül 2014'te çıkarılan 2178 sayılı kararla ise bu durum düzeltilmiş ve herhangi bir terör örgütü hedef gösterilmeden genel bir tanımlama yapılmıştır. Alınan kararla yabancı terörist savaşçılar 'terör eylemlerini planlama, hazırlama veya onlara katılma amacıyla vatandaşı olmadığı bir devletin sınırlarına seyahat eden veya silahlı çatışmalar da dahil olmak üzere terörist eğitimi alan veya veren kişiler' olarak tanımlanmıştır (Security Council Resolutions, 18.03.2019).

BMGK, 2178 sayılı kararıyla 'yabancı terörist savaşçıları' yasa dışı olarak kabul etmiş ve tüm devletlerin, etkin sınır kontrolleri ile teröristlerin veya terör örgütlerinin hareketini engellemeye çalışmasını beklemiştir (Security Council Resolutions, 18.03.2019). Bu noktada YTS'lerin sadece gittikleri ülkeye değil o ülkeye komşu 
devletlere de seyahat ederken transit kullandıkları ülkelere de ciddi tehditler oluşturduğu belirtilmiştir (Security Council Resolutions, 18.03.2019).

Fakat genel kabul gören bir terörizm kavramı olmamasından dolayı kimin terörist olarak, hangi örgütün de terör örgütü olarak tanımlanacağı tartışma konusu olmaktadır. Örneğin YPG (Halk Savunma Birlikleri), Suriye'de faaliyet gösteren ve PYD (Demokratik Birlik Partisi)'nin silahlı yapılanması olan terör örgütü, Türkiye için bir terör örgütü iken Amerika Birleşik Devletleri için bir terör örgütü değildir. $\mathrm{Bu}$ durumda uluslararası gündemde oldukça karışıklık yaratan bir durumdur.

Uluslararası Cenova Akademisinin Ekim 2014'te çıkarmış olduğu 'Uluslararası Hukuk Altında Yabancı Savaşçılar' raporunda benimsemiş olduğu tanım genel çerçeve çizmek adına daha belirleyici olmaktadır. Raporda (2014), yabancı savaşçı, 'yurtdışındaki silahlı bir çatışmada devlet dışı silahlı bir gruba katılmak için menşe ülkesini veya alışılmış ikametgahını terk eden ve öncelikle ideoloji, din ve/veya akrabalık bağları tarafından motive olan bir kişi olarak tanımlanmıştır (s.6). Bu kapsamda makalenin ilerleyen kısımlarında da Cenova Akademisinin yapmış olduğu tanım benimsenerek konu anlatılacaktır. Bu tanımlamada terörist kavramının aradan çıkartılmış olması ve ideoloji, din veya kişilik bağlarından dolayı bu tür örgütlere katılan herkesin YTS kategorisi içine alınması bu tanımın tercih edilmesine yardımcı olmuştur.

Uluslararası arenada da yabancı terörist savaşçı kavramını tanımlamaya yönelik pek çok girişim olmuştur. Yapılan yorumlara bakıldığında; David Malet, yabancı savaşşıları 'sivil çatışma sırasında isyanlara katılan, çatışan ve devletlerin vatandaşı olmayanlar' olarak tanımlamıştır (Malet, 2013: 9). Ian Bryan (2010: 117)'ın yapmış olduğu yabancı savaşçı tanımı ise 'topraklarından kopup ulus ötesi bir dava için savaşanlar' şeklinde olmuştur. Guttry, Capone ve Paulussen (2016: 2) yaptıkları tanımda yabancı savaşçı kavramını 'bir ideolojinin, dinin ya da etnik bağın/kan bağının etkisiyle harekete geçen bireylerin, vatandaşı olduğu ülkeyi ya da yaşadığı ülkeyi terk edip başka ülkede bir devletin ya da devlet dışı örgütün yanında bir silahlı çatışmaya dahil olması' olarak tanımlamaktadırlar. Thomas Hegghammer (2010: 57) ise yaptığı yorumda bir isyancı harekete katılarak bu hareketin faaliyetlerine dahil olan, çatıştığı devletle bir akrabalık bağı olmayan, para ödenerek gelmiş olmayan ve resmi bir askeri bağı olmayan gibi kriterleri belirtmiş ve bu kriterler doğrultusunda 'herhangi bir düşmana karşı terörist faaliyetleri de içeren herhangi bir askeri faaliyet için Batı' dan gelen kişiler' tanımını yapmıştır. Hegghammer'ın belirttiği bu kriterler, aslında yabancı terörist savaşçıları sınırları aşan diğer şiddetli aktör türlerinden ayırmaktadır. Özellikle paralı askerlerle yapılan karşılaştırmada aralarındaki en 
büyük farkın, paralı askerlerin maddi bir çıkarının olması ama YTS'lerin maddi çıkar amacı olmadan bölgeye gitmeleri olduğu görülür.

Yapılan tüm bu tanımlar ve alınan kararlar doğrultusunda görülmektedir ki yabancı terörist savaşçı kavramının tanımında iki kriter ön plana çıkmakta ve gerek uluslararası kuruluşlar gerekse de akademisyenler bu kriterlere bağlı kalarak YTS kavramını şekillendirmektedir. Fakat literatürde terör ve terörizm tanımının muğlak olması yabancı terörist savaşçı kavramını da etkilemektedir. Bu yüzden küresel bir tanımlama henüz yapılmış değildir.

\section{YABANCI TERÖRIST SAVAŞÇILARIN TARIHHSEL GELISŞIMII}

Yabancı terörist savaşçı kavramı DEAŞ'la beraber popülaritesini arttıran bir kavram olmasına rağmen aslında tarihini 18. yy'a kadar götürmek mümkündür. 18. yy'da gerçekleşen Amerikan Devrimi, 1821-1832 yılları arasında yaşanan Yunan İsyanı, 1835-1836 yılları arasında yaşanan Teksas Devrimi, 1936-1939 İspanya İç Savaşı ve 1948 Arap-İ́srail Savaşı gibi örnekler oldukça eski örneklerdir (Güven, 2017: 19). Flores (2016: 29-32), ilk ciddi örneklerden biri olan Amerikan Devrimin'de İngilizlere karşı savaşmak için Fransa ve İspanya başta olmak üzere Avrupa'dan ve Amerika kıtasında yer alan Haiti'den gelen yabancı savaşçılardan söz etmiştir.

Yunan İsyanında (1821-1832) Osmanlı İmparatorluğu egemenliği altındaki Yunanlılar bağımsızlık savaşı başlatmıştır. Bazı Avrupalı entelektüeller Yunanistan'1 Avrupa medeniyetinin ortaya çıktığı yer olarak kabul etmiş ve Yunanistan'a hayranlık besledikleri için onlara destek vermek adına bölgeye gitmişlerdir (Güven, 2017: 20). Destek verenler arasında en bilindik isimlerden birisi Avrupalı şair Lord Byron'dır (Güven, 2017: 20). Avrupalıların bu savaşta Yunanistan'a destek vermelerinin sebeplerinden bir başkası da dini ideoloji kapsamında Yunanlıların da Hristiyan olmaları ve Osmanlı devletinin Yunanlılara kötü davrandıklarını düşünmeleri olmuştur (Flores, 2016: 32). Teksas Devrimin'de ise Herman Ehrenberg, küçük bir monarşi kurma amacıyla yanına 120 savaşçı alarak Prusya'dan Meksika'ya gelmiştir (Demir, 2015: 1).

20. yy’daki ilk ciddi örneği oluşturan 1936-1939 İspanya İç Savaş1, İspanyol Cumhuriyetine sadık olan 'Cumhuriyetçiler' ile General Francisco Franco liderliğinde oluşturulan 'Milliyetçiler' arasında yaşanmıştır ve Macaristan, İngiltere, İtalya, Almanya, Avusturya, Sovyetler Birliği, Yugoslavya, Kanada, ABD, Fransa, Polonya gibi ülkelerden yaklaşık 40 bin yabancı savaşçının geldiği ifade edilmektedir (Güven, 2017: 22). 1939 yılında Sovyetler Birliği’nin Finlandiya’yı işgal etmesi üzerine de 10 bin İsveçlinin Finlandiya'ya gelmesi İkinci Dünya Savaşında görülen 
yabancı savaşçı örneği olmuştur (Güven, 2017: 22). 1948 Arap-İsrail Savaşında da Kanada, Amerika, Büyük Britanya ve Güney Afrika'dan gelen diaspora Yahudileri, İsrail'e destek vermek amaciyla bölgeye gitmişlerdir (Demir, 2015: 1).

1979 yılında Afganistan'ın Sovyetler Birliği tarafından işgal edilmesi ve ardından Bosna Savaş1, Kosova Savaşı, Keşmir ve Çeçenistan'da yaşanan çatışmalar ve en yakın tarihli örnek olarak Suriye İç Savaşının yaşanması Müslümanların da dini kimlik üzerinden yabancı terörist savaşçı kavramına dahil olmalarını gerçekleştirmiştir. Afganlı Müslümanlara yardım etmek amacıyla Afganistan'a gelen yabancı terrorist savaşçıların çoğu Sovyetler Birliği'nin çekilmesinden sonra da Afganistan'da kalmış ve El-Kaide terör örgütünün kuruluşuna zemin hazırlamışlardır (Güven, 2017: 37). Afganistan'da kalmayanların bir kısmı ise evlerine geri dönmüş, bir kısmı da 1992-1995 yılları arasında yaşanan Bosna Savaşında Bosnalı Müslümanlara yardım etmek için Balkanlara gitmiştir (Yalçınkaya, 2015: 31). Bu noktada, ülkelerine döndüklerinde tutuklanacak veya sınır dış1 edilecek olanlar için ise Bosna savaşı yeni cihat alanı olmuştur (Yalçınkaya, 2015: 32). Bu şekilde Müslümanlara yardım etme amacıyla yeni cihat alanlarına giden yabancı terörist savaşçılar İslamiyet ve Müslüman kimliği üzerinden radikalleşen yabancı terörist savaş̧̧ıların tarih sahnesindeki devamlılığını sağlamıştır (Yalçınkaya, 2015: 32).

Yabancı terörist savaşçıların tarihsel gelişimi incelediğinde görülmektedir ki savaşçıların geldikleri ülke veya bölge sınırlandırılamayacak kadar geniştir. Yaşanan savaşların ortaya çıkış amacı farklı olduğu gibi yabancı terörist savaşçıların geliş amaçları da ülkeden ülkeye farklılık göstermektedir. Sahip oldukları ideolojiler, dinsel veya mezhepsel farklılıklar, kişisel mağduriyetleri, muhalif düşünceleri vb. faktörler bu sürece fazlaca etki etmekte ve yabancı terörist savaşçı kavramının arkasındaki nedenlerin çeşitliliğini gözler önüne sermektedir.

\section{BALKANLAR'DA YABANCI TERÖRIST SAVAŞÇILARIN ORTAYA ÇIKMASINA SEBEP OLAN FAKTÖRLER}

Balkanlar, farklı etnik ve dini grupların yan yana yaşadığı, aralarında anlaşmazlıkların ve çatışmaların mevcut olduğu bir bölgedir. Tarihsel olarak bu anlaşmazlıklar Yugoslavya'nın dağılmasından sonra Bosna Savaşı ve Kosova Savaşı gibi oldukça kanlı savaşların yaşanmasına sebebiyet vermiştir. Bölgede arka arkaya yaşanan bu savaşlar zamanla yabancı terörist savaşçıların doğmasına ve cihatçıların Balkanlara gelmesine hatta bir kısmının bölgede kalarak başkalarının da radikalleşmesine sebebiyet vermesine neden olmuştur. 
Balkan nüfusunun radikalleşme sebepleri oldukça çeşitlidir. İlk sıralarda sayılabilecek olan sebeplerden biri dini motivasyondur. 1992-1995 tarihleri arasında yaşanan Bosna Savaşında ABD ve AB'nin çatışmadan uzak kalması ve bölgede çatışan savaşçılara Suudi Arabistan, İran ve Körfez ülkelerinin destek verip yardım etmesiyle birlikte halk Selefi-Vahhabi akımı ile yakınlaşıp silah ve lojistik destek almıştır (Domazeti, 2017: 4). Bu ülkeler Balkanlar'da camileri ve eğitim tesislerini maddi olarak desteklemenin yanı sıra genellikle genç Müslümanların Orta Doğu üniversitelerinde öğrenim görmesi için de burs vermiş ve İslam'ın muhafazakâr selefi versiyonunu birden fazla kanal aracılı̆̆ıyla Balkanlarda yaymayı amaçlamışlardır (Ignjatıjevic, 2018: 99). Bosna Savaşının sona ermesinden sonra ise bölgede kalan Arap mücahitler de çoğunluğu Sünni olan Boşnaklar arasında selefilik inancını yayma çabaları içine girmiştir (Domazeti, 2017: 4).

Günümüzde ise DEAŞ, El-Kaide gibi selefi örgütler selefilik inancı kapsamında Balkanlardan eleman temin etmektedir. Örgüte yardım eden kişilerin pek çoğu da selefilik akımı içinde yer alan kişilerdir. Kolluk görevlileri ve aşırılık yanlıları ile yapılan röportajlarda bu durum açıkça fark edilmiştir ki Balkanlar'dan giden ilk savaşçı grubu, yükümlülük duygusu ve dayanışma duygusuyla birleşerek Suriye'ye giden kişilerdir (Speckhard ve Shajkovci, 2018: 80). Bu savaşçı grubun içinde yer alan pek çok kişi zamanında Bosna Savaşına tanık olduğunu ve yardıma gelen yabancı terörist savaşçıları hatırlayarak bölgeye geldiğini ifade etmiştir (Speckhard ve Shajkovci, 2018: 80).

İkinci sırada sayılabilecek sebep de sosyal medyanın gücü ve modernleşme çağında yaşamamızdır. Ücretsiz olarak kullanılan ve üye sayısı milyarları aşan Facebook, Twitter, Instagram, Skype gibi uygulamalar üzerinden kolaylıkla örgütün propagandası yapılmakta ve örgüt kitleleri kendine çekmeyi başarmaktadır (Kursani, 2015: 40). Suriye'deki terörist gruplar da çatışmaları ihtilaf bölgesi dışında yaşayanlara canlı bir şekilde yansıtmak için sosyal medyayı ustalıkla kullanmaktadır (Speckhard ve Shajkovci, 2018: 87). Ayrıca pek çok terör örgütünün de yayın organları (gazete, dergi, televizyon vb.) mevcuttur. Bu yayın organları sayesinde dünyanın her yerine ulaşabilmektedirler.

11 Eylül saldırısı sonrası terörün İslam'la ilişkilendirilmesi ve 'İslamofobi' görüşünün yaygınlaşması da Balkan nüfusu üstünde radikalleşmeyi arttırıcı bir diğer etken olmuştur. Balkan Müslümanları yaşanan olaylardan dolayı zaman zaman aşağılanmaya varacak şekilde muamelelerle karşılaşmışlardır. Bölgede önemli 
sayılabilecek medya kuruluşlarının da Balkan Müslümanlarına psikolojik baskı uygulaması, Arap ülkelerine yönelik nefret söylemlerinin kullanılması, Hristiyanlığa geçme törenlerinin canlı olarak yayınlanması ve din değiştirmenin özendirilmeye çalışılması, Müslüman din adamlarının Hristiyan din adamları yanında ikinci sınıf vatandaş muamelesi görmesi gibi ayrılıkçı faaliyetler bu noktada endişe vericidir (Domazeti, 2017: 6). Balkan Müslümanlarının manevi değerlerinin itibarsızlaştırılmaya çalışılması, ifade özgürlükleri noktasında kısıtlamalara maruz kalmaları bazıları için bu sistemi düzeltmenin tek yolunun şiddet olduğuna dair düşüncelerini arttırmakta ve radikalleştirmelerini hızlandırmaktadır (Domazeti, 2017: 6).

Yapılan araştırmalarda Balkanlar'dan yaklaşık 218 ile 654 arasında yabancı terörist savaşçının 2012'den bu yana Suriye'de savaşmak için bölgeye gittiği bildirilmektedir (Holman, 2014: 8). Başlangiçta YTS’lerin büyük çoğunluğunun \%83'ünün El-Nusra cephesine, \%10'unun DEAŞ'a katıldığı ama 2014'ün başlarından itibaren bu durumun tersine döndüğü ve DEAŞ'a katılımının arttığı gözlemlenmiştir (Holman, 2014: 8). Genellikle ülkeler, Suriye'ye savaşmaya giden vatandaşlarının sayıları için kamuya açık veya özel olarak resmi tahminler sağlamıştır. Bu rakamlar çoğunlukla sosyal medya, topluluk kaynakları veya kolluk kuvvetlerinin soruşturmalarından toplanan bilgilere dayanmaktadır. $\mathrm{Bu}$ makalede de bu kaynaklardan elde edilen verilerle Balkan ülkelerinden Suriye'ye giden yabanc1 terörist savaşçılar açıklanmaya çalışılmıştır.

\section{BALKAN ÜLKELERINDEN SURIYE'YE GIDEN YABANCI TERÖRIST SAVAŞÇILAR}

\subsection{Kosova}

Nüfusu 1,8 milyon olan ve çoğunluğunu Müslümanların oluşturduğu Balkan ülkesi Kosova, 2014 yılından itibaren yabancı terörist savaşçıları diğer Batı ülkelerine nazaran daha fazla üretmiştir. Kosova'nın ülke profili incelendiğinde, Avrupa'nın en düşük insani gelişme endeksine ve Balkan ülkeleri arasında kişi başına düşen en düşük gelire sahip olan ülke olduğu görülmektedir (Shtuni, 2015: 12). Yetişkin nüfusun \%62'sinin eğitim düzeyinin düşük olması, 15-24 yaş grubu için işsizlik oranının \%56 olması Kosova halkının ideolojik telkin ve radikalleşmeye karşı daha savunmasız hale gelmesine sebep olmuştur (Shtuni, 2015: 12).

Balkan Araştırmaları Rapor Ağı (BIRN)'ün 2016 yılında yayınlanan ve İçişleri Bakanlığı verilerine dayandırılan raporunda, 300'den fazla Kosovalının Suriye ve Irak'a gittiği, içlerinden 70 Kosovalının da Suriye ve Irak'ta DEAŞ veya El Nusra 
Cephesi için savaşmakta olduğu bildirilmiştir (Qafmolla, 2016: 23). Çatışmalarda yaklaşık 60 Kosovalının öldürüldüğ̈̈ ve yaklaşık olarak 117 ile 120 arasındaki kişinin eve geri döndüğü düşünülmektedir (Speckhard ve Shajkovci, 2018: 84). Geri dönenler arasında sadece dört kadın olması ilginçtir. Kosovalı erkekler evlerine kadınlardan çok daha yüksek oranda geri dönmektedir (kadınların \%9'u, erkeklerin \%41'i) (Speckhard ve Shajkovci, 2018: 84). Bu durumun muhtemelen kadınların daha az maaş kazanması ve dul olduğunda tekrar evlenmeye zorlanmasindan kaynaklandığı düşünülmektedir. Ayrıca kadınların erkeklere göre kaçakçılara ödenecek parayı daha zor bulmaları da bir diğer sebep olarak gösterilmektedir (Speckhard ve Shajkovci, 2018: 84).

Kosovalı yabancı terörist savaşçılara ilk örnek verilebilecek isim; Bekim Mulollidir. Mullolli, 2013 yılında Priştina'da ABD'li iki Katolik misyonere saldırdığı için tutuklanmış Şubat 2015 'te ev hapsine alınmış ancak daha sonra kaybolmuştur. Gerçekleştirilen duruşmada hâkim Mullolli'nin Suriye'de savaşırken öldürüldügünü söylemiştir (Qafmolla, 2016: 19). Naman Demolli ise, Kosovalı bir Arnavut ve eski bir Kosova Kurtuluş Ordusu (UÇK) üyesidir (Shtuni, 2015: 13). 2012 yılında Suriye'de çatışmalara katılmak için gittiğinde Esed rejimi tarafından öldürülmüştür. Naman Demolli'nin Suriye'de öldürülmesinden sonra ise kuzeni Selim Demolli, Fidan ve Arben Demolli de DEAŞ'e katılmaya karar vermiştir (Nabolli ve Haxhiaj, 2018). Bu örneklerde açıkça görülmektedir ki aile ve akrabalık ilişkileri Suriye’ye gitme sürecine etki etmektedir.

2017 Şubat'inda, eskiden imamlık yaptığı bilinen ve daha sonra DEAŞ'a katılan Ridvan Hakifi de Suriye'deki çatışmalar sırasında öldürülmüştür (Sputnik, 2017). 20 Mart 2014'te Niğde saldırısında da yabancı terörist savaşçılar kolluk kuvvetlerine saldırarak bir asker ve bir polisi şehit etmiş, bir kamyon şoförünü de öldürmüşlerdir (Holman, 2014: 8). Saldırıyı gerçekleştirenlerden biri İsviçre'de yaşayan Kosovalı Çendrim Ramadani isimli teröristtir ve ailesine 'Suudi Arabistan'a dil eğitimine gidiyorum' diyerek yanlarından ayrllıp Suriye'ye gitmiştir (Saymaz, 2017: 15). Gerçekleştirdikleri saldırı sonucunda da mahkeme, Çendrim Ramadani için $5 \mathrm{kez}$ ağırlaştırılmış müebbet hapis ve 174 yıl 6 ay hapis ile 225 bin TL idari para cezası vermiştir (Habertürk, 2018).

\subsection{Arnavutluk}

Arnavutluk için elde edilen rakamlar Kosova için elde edilen rakamlardan daha düşüktür. Arnavutluk hükümetinin açıklamalarına göre 2012'den bu yana, 13 kadın 
ve 31 çocuk olmak üzere 100 'den fazla Arnavut Suriye'deki terör örgütlerine katılmıştır (Bogdani, 2016: 4). Vlado Azinovic'in 2018'de hazırladı̆̆ 1 bölgesel raporda ise 2012-2017 arasında 96 Arnavutluk vatandaşının Suriyedeki terör örgütleri saflarında yer aldığı belirtilmiştir (s.4). Arnavutluk'ta Suriye'ye giden kişilerin çoğunluğu illegal faaliyet gösteren camilerde radikalleşmişlerdir ve bu camiler muhafazakâr Selefi geleneğine ait olup DEAŞ ve El Nusra Cephesi için terörist toplamakla bağlantılıdır (Bogdani, 2016: 5). Bağımsız bir analist olan Adrian Shtuni, DEAŞ'a katılan Arnavutların 25 ila 35 yaşları arasında olduğunu savunmuştur fakat Arnavutluk polisinin kamuoyuna açıkladığı verilerde tespit edilen yabancı savaşçıların 19 ila 29 yaşları arasında olduğu ifade edilmiştir (Drymishi, 2017: 31).

Arnavutluk’ta 35 yaşındaki Genci Balla ve Bujar Hysa liderliğinde oluşturulan bir ağın bilinen yabancı terörist savaşçı oranının yarısından sorumlu olduğu düşünülmektedir (Milton, Price, Ubaydi, 2014: 11). Bu iki isimle birlikte din adamı olan diğer isim Gert Pashja da terörist amaçlı insanları işe almaktan, nefreti kışkırtmak ve terör eylemlerine çağrı yapmaktan suçlu bulunup 17 yıl hapis cezasına çarptırılmıştır (Koleka, 2016). 20 Mart 2014'te Niğde saldırısını gerçekleştiren üç teröristten biri de Almanya doğumlu Arnavut vatandaşı, Benyamin Xhu'dur ve Yargıtay'ın onadığı kararla birlikte 4 kez ağırlaştırılmış müebbet, 179 yıl 6 ay hapis cezası almıştır (Habertürk, 2018). Arnavut bir baba ve Çinli bir annenin oğlu olarak doğan Xhu, annesiyle babasının ayrılmasından sonra bir süre dedesiyle beraber yaşamış ardından Almanya'ya giderek Çeçenlerin fazlaca bulunduğu bir caminin cemaatine katılmıştır (Saymaz, 2017: 14). Suriye'de İç Savaşın başlamasıyla radikalleşmesi de hızlıca artan Xhu'nun artık tek amacı cihat'a katılmak ve şehit olmak olmuştur (Saymaz, 2017: 14). 2014 yılında gerçekleşen ve DEAŞ'ın Türkiye'deki ilk kanlı eylemi olarak bilinen Niğde eyleminin içinde de bu şekilde yer almıştır.

Gerçek adı Almir Daci olan fakat Ebu Belkisa olarak tanınan Arnavut terörist ise, 2016 yılında öldürülmüştür (Nabolli ve Haxhiaj, 2018). Suriye'de mi ya da Irak'ta mı öldürüldüğü konusunda net bir bilgi yoktur. Fakat; DEAŞ adına Arnavutluk'u tehdit eden bir video yayınladıktan sonra bilinirliğinin arttığı ve eşi ve çocuklarının hala Suriye'de olduğu bilinmektedir (Haberler, 2016). ABD’nin gerçekleştirdiği hava saldırılarında DEAŞ’ın dış terör saldırı planlayıcısı olan Jetmir İsmaili, dış terör saldırı koordinatörü olan Razim Kastrati ve Güneydoğu Avrupa'dan DEAŞ'l1 teröristleri alarak Suriye'ye ulaşmalarına yardımcı olan İrfan Haqifi de öldürülen isimler arasındadır (Coalition Removes ISIS Terrorists From Battlefield, 2017). 


\subsection{Bosna Hersek}

2015 yılında yayınlanan rapora göre, Bosna Hersek Avrupa ülkeleri arasında en yüksek yabancı terörist savaşçı oranına sahip olan ülkedir (Gadzo, 2016). Balkan Araştırmaları Rapor Ağı (BIRN) tarafından yayınlanan raporda yaklaşık 120 erkeğin DEAŞ ve El-Nusra Cephesi saflarında Suriye'de çatışmalara katıldığı düşünülmekte ve bu rakamın 30'unun çatışmalarda öldüğü 50'sinin de Bosna'ya geri döndüğü ifade edilmektedir (Dzidic ve Jahic, 2016: 15). Peter R. Neumann (2015) tarafından hazırlanan International Centre for the Study of Radicalization (ICSR) raporuna göre ise Bosna'dan 330 kişi Suriye'deki çatışmalara katılmak için ülkesinden ayrılmıştır. Yine aynı raporda Suriye'deki çatışmalara katılan Bosna Hersekli erkeklerin yaş ortalamasının 32 olduğu ve Bosna Savaşına tanıklık edenler ve daha genç olanlar olarak ikiye ayrılabileceği ifade edilmiştir (Azinović ve Jusić, 2015: 32). Bu rakamlarla diğer Balkan ülkelerine nazaran Bosna Hersek için yabancı terörist savaşçı oranının yüksek olduğu açık bir gerçektir. Bunun en büyük nedeninin de Bosna Savaşı zamanında başka ülkelerden yardıma gelen kişilere minnet ve şükran duyma duygusu olduğu savunulabilir.

Bosnalı cihadi savaşçıların radikalleşmeleri, ülkenin resmi İslami ilişkiler kurumu olan 'İslam Topluluğu'ndan bağımsız faaliyet gösteren ve resmi olmayan camilerde gerçekleşmiştir (Güven, 2017: 86). Ülkenin dağlık ve kırsal kesimlerinde faaliyet gösteren bu camiler, hükümet tarafından kapatılmakta ve eleman temini engellenmeye çalışılmaktadır. Fakat bu önlemin Bosna Hersek'in Avrupa ülkeleri arasında en yüksek yabancı terörist savaşçı oranına sahip ülke olduğu hatırlandığında çok etkili olmadığı görülmektedir.

Yapılan araştırmalarda zaman zaman yabancı terörist savaş̧̧ıların isimlerine de yer verilmiştir. Özellikle spesifik eylemleri üstlenen kişilerin isimlerini açık kaynakta bulmak mümkündür. Bu noktada, basına yansıyan isimlerden biri İbrahim Delic adında Bosna'nın merkezinde, Gornja Bocinja köyünde yaşamını sürdüren ve çobanlık yapan kişidir (Dzidic ve Jahic, 2016: 10). Bu kişi, Bosna Hersek mahkemesi tarafindan DEAŞ'a katılmak ve yardım etmek suçuyla yargılanmaktadır. Bosna Hersek Araştırma ve Güvenlik Ajansı (SIPA), İbrahim Delic'in 15 kişiyle birlikte Eylül 2014'te "Şam" koduyla gerçekleştirilen bir operasyonda tutuklandığını açıklamıştır (Gadzo, 2016). Örgüte eleman temini sağlamak, seyahatlerini düzenlemek ve finanse etmek suçuyla yargılanmaktadır. 
7 Ağustos 2014'te Bağdat'da gerçekleşen intihar saldırısını düzenleyerek 24 sivilin yaşamını yitirmesine sebep olan isim Emrah Fojnica da Bosna Hersek vatandaşı olan yabancı terörist savaşçılardan biridir (Güven, 2017: 84). Emrah Fojnica'nın babası Hamdo Fojnica'da Suriye ve Irak'taki terör faaliyetlerine finansal destek sağlamak, bu bölgelere savaşmaya gitmek ve etrafındaki insanları da savaşmaya gitmeye kışkırtmak gibi suçlardan dolayı tutuklanmıştır (Güven, 2017: 85). Emrah Fojnica'nın babasının da bu sürecin içinde yer alması radikalleşme de aile ve akraba bağlarının etkisini ortaya koyan bir örnek olmuştur. 28 Ekim 2011 tarihinde Saraybosna'da ABD Büyükelçiliğine gerçekleştirilen saldırıyı yapan kişi Mevlid Yaşaerviç de Sirbistan'ın Novi Pazar bölgesinde bulunan Selefi/Vahabi grubunun mensubu bir yabancı terörist savaşçıdır (Güven, 2017: 84).

Mart 2008'de Edis Velic ve 3 terörist Katolik kiliselerine ve uluslararas1 kuvvetlere yönelik saldırılar planladıklarının tespit edilmesi üzerine tutuklanmışlardır (Alic, 2019). Yapılan araştırmalar sonucunda eylem girişimde bulunmak isteyen teröristlerin Saraybosna'da Vahhabi grubuna dahil olduğu anlaşılmış ve Edis Veliç'in de daha önce Çeçenistan'a savaşmaya gittiği ortaya çıkmıştır (Güven, 2017: 84). 2007 yılında Saraybosna'da görülen davada 'yabancı güçlerin Irak ve Afganistan'dan çekilmeleri için bir Avrupa ülkesinde eylem yapma hazırlığında olma' gerekçesiyle 1976 doğumlu Bajro İkanoviç patlayıcı temin etmekten sekiz yıl, Senad Hasanoviç yasa dışı silah ve patlayıcı bulundurmaktan 2,5 yıl hapse mahkûm edilmiş ve ardından beşinci zanlı olarak görülen Amir Bayriç de temmuz ayında 2 yıl hapse çarptırılmıştır (Hürriyet, 2007).

2007 yılında ABD’nin Viyana büyükelçiliğine saldırı düzenlemeye çalışan 42 yaşındaki Michaela Raz da güvenlik kontrolünden geçerken metal detektörünün alarm vermesi üzerine kaçmış ve eylemini gerçekleştirememiştir (Sondakika.com, 2007). 2009'da Bosna doğumlu ABD vatandaşı olan Adis Medunjanin ise New York metrolarına intihar bombası saldırısı planlamasındaki rolü nedeniyle hapis cezasına çarptırılmıştır ve bu saldırı emrini El-Kaide militanlarından aldığı düşünülmüştür (Bosnahersek.ba, 2013). 27 Nisan 2015 y1lında selefi topluluğun bir üyesi olan Nerdin İbriç ismindeki kişi ise, Zvornik polis merkezine dalarak bir polis memurunu öldürmüştür (Bjelic, 2015).

\subsection{Makedonya}

Makedonya'dan Suriye'ye giden kişi sayısı azımsanmayacak kadar çoktur. Şimdiye kadar anlatılan ülkeler arasında Bosna Hersek ve Kosova'dan sonra üçüncü sırada yer almaktadır. Polis tahminlerine göre, yaklaşı 110 Makedonya vatandaşı Suriye 
ve Irak'ta bulunmaktadır ve çatışmalarda 27 'sinin öldüğü, 70 'ten fazla yabanc1 terörist savaşçının ise evine geri döndüğü bildirilmektedir (Marusic, 2016: 25). Vlado Azinovic'in 2018'de hazırladığ 1 bölgesel raporda ise 2012-2017 yılları arasında Makedonya'dan Suriye'ye giden 140 kişi vardır ve bu sayının 14'ü kadındır (s.4). Suriye ve Irak'ta terör örgütlerine katılan Makedonların çoğu, Üsküp ve yakınlardaki Arnavut köylerinden gelmektedir ve başkentte yer alan başlıca iki etnik Arnavut bölgesi ise Cair ve Gazi Baba'dır (Marusic, 2016: 25). Bu noktada Makedon YTS'lerin bazıları aynı sokakta, Cair'deki Jaja Paşa ve Tutunsuz camilerinin yakınlarında yaşamış ve tanıştıktan sonra birbirlerinin fikirlerinden etkilenerek radikalleşmişlerdir (Sutarov, 2017: 106-107).

Makedon yabancı terörist savaşçılarının çoğunun dini eğitiminin olmaması, çok fakir ailelerden gelmeleri, büyük ölçüde eğitimsiz olmaları ve cezai geçmişleri bulunması ortak özellikleridir ve bazıları eski Kosova Kurtuluş Ordusu (UÇK) üyeleri arasında yer almıştır (Sutarov, 2017: 107). Gerçek adı Bekim Fidani olan ama 'Ebu Usama' olarak bilinen Arnavut kökenli terörist DEAŞ saflarında oldukça aktif olarak yer almıştır (Sutarov, 2017: 107). 2014 yılında, Üsküp'ten Ebu Muhammed El-Jawlani tarafindan grubun askeri operasyonlarının lideri olarak atanan Abdul Jashari de Makedon yabancı terörist savaşçlardan biridir (Sutarov, 2017: 107). Stefan Stefanovski ise tıp fakültesi mezunu saygın bir doktor iken Tutunsuz Camii'ni ziyaret ettikten sonra 'yaralı DEAŞ savaş̧̧larını tedavi etmek için Suriye'ye gitti' iddiasıyla iki yıl hapis cezasına çarptırılmıştır (Pajaziti, 2016). Aynı davada Stefanovski ve Isa Fuga dört buçuk yıl hapis cezasına, Abdullah Abdullahi üç yıl hapis cezasına, Eroll Rustemi dört yıl hapis cezasına, İmer Muhamedi de iki yıl hapis cezasına çarptırılmıştır (Pajaziti, 2016). DEAŞ’ın Türkiye'deki ilk eylemi olma özelliği taşıyan Niğde saldırısını gerçekleştiren üç teröristten biri de 1995 doğumlu Makedonya'lı Muhammed Zekjiri'dir (Saymaz, 2017: 13). 18 yaşına basmadan Suriye'ye gelen Zakiri, eylemi gerçekleştirmek için yola çıkmadan önce uzun süre Halep'teki kampta kalmıştır (Saymaz, 2017: 13).

\subsection{Karadă}

Karadağ yaklaşık 620.000'lık nüfusu ile \%20'sini Müslümanların oluşturduğu uzun ve köklü bir geçmişe sahip olan bir devlettir (Tomovic, 2016: 32). Vlado Azinovic (2018)'in hazırladığı bölgesel raporda Karadağ'dan 18 erkek, 5 kadın ve 4 çocuk olmak üzere toplam 27 kişinin gittiği ifade edilmektedir (s.4). Balkan Araştırmaları Rapor Ăğ (BIRN) tarafından yayınlanan raporda ise 13 Karadağ vatandaşının, 
Suriye ve Irak'ta DEAŞ veya El-Nusra Cephesi altında savaşmak için ülkeyi terk ettiği ve dördünün çatışmalarda öldüğü bildirilmiştir (Tomovic, 2016: 37).

Kuzey Plav kasabasından gelen on sekiz yaşındaki Ernad Huseinoviç, Suriye ve Iraktaki çatışmalarda öldürüldüğü bilinen Karadağlı yabancı terörist savaşçılardan biridir (Tomovic, 2016: 33). Almanya üzerinden Suriye'ye gittiği bilinen Huseinoviç, 20 Ocak günü gerçekleştirilen bombalı saldırı sonucu öldürülmüş ve altı ay kadar DEAŞ'ın içinde yer almıştır (Tomovic, 2016: 33). DEAŞ ile Suriye'de savaştığı bilinen diğer üç Karadağlı teröristte Podgorica'dan Mirza Haklaj, Rozaje'den Adis Salihoviç ve Bar'dan Damir Slakoviç'dir (Tomovic, 2016: 33).

\subsection{Sirbistan}

Vlado Azinovic'in 2018'de hazırladığı bölgesel raporda; 37 erkek, 12 kadın ve 10 çocuğun 2012-2017 yıları arasında Sırbistan'dan Suriye'ye gittiği belirtilmiştir (s.4). Sırbistan'dan Suriye'ye giden erkeklerin yaş aralığı 22 ve 35 yaşları arasındayken, kadınların yaş aralığının 19 ve 28 arasında olduğu ve çoğunun sadece liseyi bitirdiği belirtilmiştir (Speckhard ve Shajkovci, 2018: 85). Makfirete Saciri, BIRN (2016)'e verdiği röportajda 2013 y1lında eşi Ferat Kasumoviç ve erkek kardeşi Fahredin Saciriyle birlikte Suriye'ye gittiğini söylemiştir (s.38). Çocuğunu da yanına alarak Türkiye üzerinden Suriye'ye geçtiklerini ve DEAŞ'ın başkenti olarak kabul edilen Rakkada üç ayını geçirdiğini açıklamıştır (Maksimovic, Ristic, Dragojlo, 2016: 38). 20'li yaşlarının sonlarında ve etnik bir Roman olan Saciri, kadınlar ve çocuklar için ayrı bir apartman olduğunu ve kendisinin çocuğuyla birlikte buraya yerleştirildiğini belirtmiştir (Maksimovic, vd. 2016: 38). "Fransa, Almanya ve İsviçre'den kadınlar vard1... Zagreb ve Belgrad'dan kadınlar vardı, ancak kadınların çoğu Bosnalıydı” şeklinde kaldıkları yerdeki kadınları anlatmıştır (Maksimovic, vd. 2016: 38). "Etrafımda neler olduğunu zar zor anladım ama her zaman korktum... Kendimden daha çok çocuğum için korktum" şeklinde hislerini de açıklamıştır (Maksimovic, vd. 2016: 38). Kardeşi Fahredin Saciri'nin savaşırken öldüğünü ve kardeşi ölünce Şubat 2014'te Sırbistan'a geri döndüklerini çünkü kocasının bu şekilde emrettiğini de eklemiştir (Maksimovic, vd. 2016: 38). Saciri'nin kocası Kasumoviç, Belgrad'daki yüksek mahkemede dört kişiyle birlikte Suriye'de terör suçu işlemek, başkalarının işlemesine destek olmak ve onları eğitmekle yargılanmaktadır (Maksimovic, vd. 2016: 39).

Kolluk kuvvetlerinin tahminlerine göre, kadınlar ve çocuklar da dahil olmak üzere 50 Sırp, 2012 ve 2016 tarihleri arasında Suriye ve Irak'a gitmiştir (Maksimovic, vd. 2016: 38). Gidenlerin çoğunluğu da Saciri gibi Sırbistan'ın son derece 
marjinalleşmiş Roman topluluğundandır (Maksimovic, vd. 2016: 38). Bu sayıdan 26'sının halen Suriye ve Irak' ta DEAŞ ya da El Nusra Cephesi saflarında çatıştığı, 8'inin çatışmalarda öldüğü ve 7'sinin ise Sırbistan'a döndüğü düşünülmektedir (Maksimovic, vd. 2016: 43).

Sırbistan'da yabancı terörist savaşçıların yasadışı camiler, insani yardım kuruluşları ve din okulları ya da arkadaşları aracıllı̆̆yla bizzat radikalleştiği savunulmaktadır (Ignjatıjevic, 2018: 99). Sırbistan'da radikalleşmenin yoğun olarak yaşandığı yerler, ülkenin güneybatısında yer alan Sandzak'ın Boşnak Müslüman bölgesinin çoğunda ve Smederevo, Zemun gibi Roman nüfusun fazla olduğu şehirlerindedir (Ignjatijevic, 2018: 99). Radikalleşen gençleri Suriye'ye göndermek için aracı olan örgütlerden biri, Novi Pazar'daki İslami gençlik Örgütü 'Furkan'dır (Ignjatijevic, 2018: 99). 2009 y1lında kurulan ve bir sivil toplum kuruluşu olarak tescil edilen bu dini örgüt, Sandzak bölgesinde birtakım gençleri cezbetmiştir (Ignjatıjevic, 2018: 99). Saha faaliyetlerinin yoğun olması ile bilinen örgütte dini fanatizm oldukça yüksek ve katı bir dini inanç söz konusudur (Corovic, 2017: 128).

Furkan'ın yoğun faaliyetleri, radikal İslam'ın Sırbistan'da yayılmasını kolaylaştırmış ve Sırp gençlerinin DEAŞ'a katılmaya ilgi duymasına neden olmuştur (Corovic, 2017: 128). Basında çıkan haberlere ve iddianamelere göre bu örgüt, Sırp vatandaşları için radikalleşme noktası olmanın yanı sıra, diğer ülkelerden gelen bireyler için de Suriye yolunda dinlenmek için alternatif bir durak olarak görev yapmıştır (Ignjatıjevic, 2018: 99). Furkan etrafında toplanan topluluk, Bosna Hersek'teki Gornja Maoca ve Osve gibi tanınmış radikal kümelerle de yakın ilişki kurmuştur (Ignjatıjevic, 2018: 100). Ulusal ve bölgesel düzeyde ilişkiler kurup Batı Avrupa ülkelerindeki diasporalarının da desteğinin alarak Almanya veya Avusturya'dan gelen imamların konferanslar ve vaazlar vermesini sağlamışlardır (Ignjatijevic, 2018: 100).

\section{HUKUKSAL DURUM}

2014 y1lında DEAŞ'ın hilafetini ilan etmesi tüm dünyadan giden yabancı terörist savaşçı sayısını arttırdığı gibi Balkanlardan giden yabancı terörist savaşçıların sayısını da arttırmıştır. Devletler artarak büyüyen bu rakamlarla nasıl mücadele edeceğini tam tespit edemeden 2017 yılıyla birlikte DEAŞ'ın askeri anlamda zayıflatılması ve yabancı terörist savaşçıların evlerine geri dönmeye başlaması sorunu başka bir boyuta taşımıştır. 2014-2015 döneminde Arnavutluk, Kosova, Bosna Hersek ve Makedonya devletleri Suriye'ye giden vatandaşlarının sayılarının 
her geçen gün artması üzerine radikal vaizlerin ve işverenlerin tutuklanması amacıyla polis eylemleri gerçekleştirerek Suriye'ye gitmek için aracı olan kişilerin etkisini azaltmaya çalışmıştır (Sutarov, 2018: 171). Bu tedbirler, radikal faaliyetleri caydırmak ve savaş bölgelerine seyahat etmeyi azaltmak adına olumlu olmuştur. $\mathrm{Bu}$ noktada hükümetler sadece kişileri engelleme imkanını kullanmamış aynı zamanda çevrimiçi propaganda ve radikalleşmeye karşı da harekete geçerek yeni organlar oluşturmuşlardır (Sutarov, 2018: 171).

Makedonya 'Radikalleşmeyi Durdurma ve Teröre Katılım' projesini başlatmıştır (Sutarov, 2018: 173). Sırbistan, '2017-2020 yılları arasında Gençler Arasında Bağımlılıkların, Şiddetin ve Her Türlü Aşırılık Yanlılıklarının Önlenmesi Stratejisi'ni hazırlamıştır (Sutarov, 2018: 173). Bosna Hersek de 'Takfir İdeolojisi ve Şiddet Aşırılığının Analizi’ projesini yaparak imamlar için seminer ve eğitimler yapmıştır (Sutarov, 2018: 173). Bölgedeki etnik ve dini çeşitlilik göz önüne alındığında dinler arası diyalog da oldukça güçlü bir aşırıcılıkla mücadele aracı olarak görülmüştür (Sutarov, 2018: 173). Bu süreçte sivil toplum kuruluşları da fazlaca rol üstlenmişlerdir. Araştırma, kamuoyu bilinçlendirme kampanyaları, konferans, çalıştay ve yuvarlak masa organizasyonu, farklı projelerin ulusal veya yerel düzeyde uygulanması dahil olmak üzere pek çok şekilde destek olmuşlardır (Sutarov, 2018: 173).

Hükümetler kendi ulusal ceza yasalarında da değişikliğe giderek vatandaşlarının dış çatışmalarda savaşmak için ülkelerinden ayrılmalarını suç kapsamına dahil etmiştir (Spahiu, 2018). Örneğin, Kosova Parlamentosu Nisan 2015'te, vatandaşlarının başka yerlerdeki çatışmalara yabancı terörist savaşçı olarak gitmelerini yasaklayan yasayı çıkarmıştır (Kursani, 2015: 44). Arnavut parlamentosu da Şubat 2014'te silahlı çatışmalara katılma ve yabancı ülkelerdeki askeri gruplarla birleşme olayını 8 yıla kadar hapis cezasına çarptırılabilecek bir suç olarak kabul eden yasa paketini onaylamıştır (Bogdani, 2016). Bu mevzuat değişiklikleri insanların gidişini azaltmada olumlu sonuçlar vermiş fakat geri dönenleri yargılama noktasında bir avantaj sağlamamıştır (Global Risk Insight, 2018). Çünkü insanların Irak ya da Suriye'ye seyahat kayıtları mevcut olsa bile El-Nusra Cephesi ya da DEAŞ gibi terör örgütlerinin gizli doğası nedeniyle gidenlerin bu örgütlerde yer aldığına dair şüphe duymanın ötesinde resmi bir belge temin edilememiştir. Bu durum da geri dönen kişilerin düşük oranlarda ceza almalarına yol açmıştır. 


\section{SONUÇ}

Yabanc1 terörist savaşçı kavramı tarihsel olarak yeni değildir. 21. yy'daki en ciddi örneği Suriye İç Savaşı oluştururken 20. yy'da ki en ciddi örneği de 1936-1939 İspanya İç Savaşı oluşturmuştur. Yaklaşık 40.000 ile 50.000 arasında insanın bu bölgeye gittiği ifade edilmektedir (Barrett,2017: 7). Bu örneklerin yanı sıra Arapİsrail Savaşı, Afganistan'ın İşgali, 1992-1995 Bosna Savaşı, 2003 yılında Irak’ın İşgali gibi pek çok çatışmada da yabancı terörist savaşçı örneklerine rastlamak mümkündür. Bu örnekler YTS kavramının Suriye İç Savaşıyla veya radikal cihatçı hareketlerle sınırlandırılamayacağını açıkça göstermektedir. Köken olarak oldukça eski olan ve ideolojiler noktasında (Hristiyanlık, Komünizm, İslami cihat anlayışı vs.) zamanla farklılaşan YTS kavramının kapsamına Sovyetler Birliği'nin Afganistan'ı işgalinden sonra cihat anlayışı dahil olsa da tüm olgu radikal cihatçılara veya İslamiyete atfedilemez.

En güncel örnek olan Suriye İç Savaşı incelendiğinde, terör örgütlerinin bölgedeki karışıklıktan yararlanarak güçlerini arttırmalarından sonra bölgeye gelen yabancı terörist savaşçıların sayısının bir hayli arttığı görülmektedir. Balkanların geneline bakıldığında yaklaşık 845 kişinin Suriye'ye gittiği tahmin edilmektedir (Barrett,2017: 11). Bu rakam karşısında Balkan devletleri yabancı terörist savaşçı kavramı için önleyici tedbirler almaya başlamıştır. Fakat yabancı terörist savaşçı kavramı gelip geçici bir kavram değildir ve Balkanların yakın geleceğine ciddi güvenlik sorunu oluşturabilecek bir faktördür. $\mathrm{Bu}$ nedenle Balkan ülkeleri iç sebeplere çözüm bulmadıkça vatandaşlarının radikalleşmelerinin de belirli düzeylerde devam etmesi ve bu ülkeleri tehdit eden örgütlerin sadece isimlerinin değişecek olması yüksek ihtimal dahilindedir.

2017 yılı itibariyle yapılan askeri operasyonlarla bölgedeki terör örgütlerinin zayıflatılması ve geri dönenlerin artması YTS kavramının farklı bir boyutunu ortaya çıkarmıştır. Balkan devletleri geri dönen bireylerin ideolojik olarak zarar görmüş olması, silahlarla eğitilmiş olmaları, muhtemelen psikolojik olarak daha az sağlıklı olmaları ve çatışma bölgesindeki travmatik deneyimlerini göz önünde bulundurduğunda ülkelerine yol açabilecekleri olası tehditlerden endişelidir. Bazılarının şiddet içeren aşırıcılığa girebileceği veya uzun vadede ülkelerinde terörizm için katalizör görevi görebileceği ihtimali de duyulan endişenin diğer boyutudur. $\mathrm{Bu}$ noktada devletler savaş alanını görmüş, deneyim kazanmış vatandaşlarının toplum için nasıl bir tehdit yarattıklarını tam olarak tahmin 
edememektedir. $\mathrm{Bu}$ nedenle devletler geri dönenlerin fark edilmeden toplum içine karışmasını ve eylem planı yapma ihtimallerini en aza indirmek için çabalamaktadır.

Balkan devletleri aynı zamanda yabancı terörist savaşçıların çatışmadaki gerçek rollerini ve kaç kişinin savaşa aktif olarak dahil olduğunu tespit etmenin yarattı̆̆ zorluktan dolayı da büyük bir belirsizlik hissetmektedir. Karşılarında bir devlet yapısı bulunmadığı için bireylerin işlediği suçlar adına delil bulmakta zorlanmaktadırlar. $\mathrm{Bu}$ noktada, savaş başladığında bazılarının gidiş sebebi 'Suriye halkına' yardım etmek olmuş ve bölgede kaldıkça faaliyetleri zamanla farklılık göstermiştir. Başlangıçtan itibaren amacı cihat olup Suriye'ye ve Irak'a giden yabancı terörist savaşçıların ise daha büyük tehdit oluşturacağı genel kanıdır ve geri dönenleri 'cihatçı' veya 'cihatçı değil' diye ayırmak en büyük problem olarak gözükmektedir.

Genel çerçeveden bakıldığında, yabancı terörist savaşçı kavramının belirsizliği, büyük ölçüde bir deneme yanılma süreci gibi gözükmektedir. Devletler başarılı olan politikaları uygulamaya devam ederken baskıcı önlemlerle çözümler üretmekten ziyade araştırmaya ve bilinçlendirmeye, sivil toplum kuruluşlarının projelerini desteklemeye odaklanmalıdır. Çünkü her ne kadar yabancı terörist savaşçı kavramı son y1llarda düzenlenen askeri operasyonlar sonucu azaltılmış olsa da hala radikalizm ve şiddet içeren aşırılıktan kaynaklanan güvenlik sorunları mevcuttur. Balkanların kırılgan siyasi yapısı ve sosyo-ekonomik durumu da göz önüne alındığında bu faktörlerin göz ardı edilmemesi gerektiği açıktır. Diğer taraftan devletlerin YTS kapsamında algıladıkları saldırı tehdidi de gerçektir ancak sınırlıdır, alarm zilleri uzun zamandır çalmasına rağmen yabancı terörist savaşçıların geri dönüşünün uzun vadede ne gibi bir etkisinin olacağı halen belirsizliğini korumaktadır. 


\section{KAYNAKÇA}

ABD’nin Saraybosna Büyükelçiliğine Yapılan Saldırı. (Eylül, 2013). Erişim Tarihi: 20 Mayıs 2019. https://www.bosnahersek.ba/abdnin-saraybosna-buyukelciligineyapilan-saldiri/.

Albanian ISIS Militant Reported Dead. Erişim Tarihi: 22 Mayıs 2019. https://balkaninsight.com/2016/04/04/albanian-fighter-of-isis-loses-his-life-0404-2016/.

Alic, A. (2019). Bosnia: Catching Up with ‘Terrorists'. Center for Security Studies.

Azinovic, V. (2018). Understanding Violent Extremism in The Western Balkans. Brıtısh Councıl. Erişim Tarihi: 15 Mart 2019. https://www.britishcouncil. me/sites/default/files/erf_report_western_balkans_2018.pdf

Azinovic, V. ve Jusic, M. (2015). "The Lure of The Syrian War: The Foreign Fighters' Bosnian Contingent", Atlantic Initiative, 1-86.

Barrett, R. (2017). Beyond The Caliphate: Foreign Fighters And The Threat Of Returnees. The Soufan Center.

Bjelic, A. (2015). Bosna Hersek’te neler oluyor? Erişim Tarihi: 21 Mayıs 2019. https://www.bosnahersek.ba/bosna-hersekte-neler-oluyor-2/.

BM Güvenlik Konseyi 2170 Sayılı Kararı. (2014). Erişim Tarihi: 18 Şubat 2019, http://unscr.com/en/resolutions/doc/2170

BM Güvenlik Konseyi 2178 Sayılı Kararı. (2014). Erişim Tarihi: 18 Şubat 2019, http://unscr.com/en/resolutions/doc/2178

Bogdani, A. (2016). Albania Faces 'Jihadi Fighters in the Shadows' Threat. Balkan Invest1gatıve Reporting Network. 4-9.

Bogdani, A. (2016). Shqipëria përballet me rrezikun e "luftëtarëve xhihadistë në hije" Erişim Tarihi: 20 Mayıs 2019. https://www.reporter.al/shqiperia-perballetme-rrezikun-e-luftetareve-xhihadiste-ne-hije/.

Bosnia Brings Back, Detains Islamic Fighter From Syria. Erişim Tarihi: 20 Nisan 2019. https://www.balkans.com/article/us-bosnia-syria/bosnia-brings-backdetains-islamic-fighter-from-syria-idUSKCN1RW0AP. 
Bosnia Plans Captured ISIS Fighters Return From Syria. Erişim Tarihi: 22 Şubat 2019. https://balkaninsight.com/2019/02/20/bosnian-plans-captured-isis-fightersreturn-from-syria/.

Bryan, I. (2010). Sovereignty and the Foreign Fighter Problem. Orbis, 54(1). 115129.

Coalition Removes ISIS Terrorists From Battlefield. (Ağustos,2017). Erişim Tarihi; 1 Nisan 2019. https://dod.defense.gov/News/Article/Article/1266520/coalitionremoves-isis-terrorists-from-battlefield/source/GovDelivery/.

Corovic, A. (2017). Radicalization İn Serbia: The Youth Of Sandžak Between A Hammer And An Anvil. Atlantic Initiative. 125-136.

Demir, H. (2015). Yabancı Savaşçılar ve Homegrown Teröristler, Türkiye Ekonomi Politikaları Araştırma Vakfi, 1-11.

Domazeti, R. (2017). Balkanlar'da Daeş Riski: Gençler Üzerine Sosyopolitik Bır Analiz. İnsani ve Sosyal Araştırmalar Merkezi, 1-11.

Drymishi, A. (2017). Radicalization and the Governance of Islam in Albania. Atlantic Initiative. 21-31.

Dzidic, D. ve Jahic, A. (2016). Bosnia 'Failing to Share Terror Threat Intelligence' Balkan Investıgatıve Reporting Network. 10-17.

Flores, M. (2016). Foreign Fighters Involvement in National and International Wars: A Historical Survey. Guttry A. Capone, F. Paulussen, C. (Ed.) Foreign Fighters Under International Law and Beyond içinde (27-47 ss.). The Netherlands: Asser Press. https://www.springer.com/gp/book/9789462650985

Foreign Fighters Under International Law. (2014, Ekim). Geneva Academy of International Humanitarian Law and Human Rights. Erişim Tarihi: 10 Mayıs $2019 . \quad$ https://www.geneva-academy.ch/joomlatools-files/docman-files/ Publications/Academy\%20Briefings/Foreign\%20Fighters_2015_WEB.pdf

Gadzo, M. (2016). Ibrahim Delic: Bosnian accused of aiding ISIL in Syria. Erişim Tarihi: 3 Mart 2019. https://www.aljazeera.com/indepth/features/2016/07 /ibrahim-delic-bosnian-accused-aiding-isil-syria-160714103407678.html 
Guttry, A. Capone, F. ve Paulussen. C. (2016), Foreign Fighters Under International Law and Beyond, The Netherlands: Asser Press.

Güven, İ.F. (2017). Sosyal İnşacılık Bağlamında Bosna-Hersek’te Yabanc1 Savaşçılar ve Güvenlik Tartışmaları. (Yüksek Lisans Tezi). Yalova Üniversitesi.

Haberler. (2016). DAEŞ'e Katılan Arnavut Vatandaşı Öldürüldü. Erişim Tarihi: 12 Nisan 2019. https://www.haberler.com/daes-e-katilan-arnavut-vatandasiolduruldu-8322585-haberi/.

Hegghammer, T. (2010). The Rise of Muslim Foreign Fighters: Islam and the Globalization of Jihad. International Security, 35(3), 53-91.

Holman, T. (2014). Foreign Fighters from the Western Balkans in Syria. Combating Terrorism Center (CTS) SENTINEL, 7(6), 8-13.

Hürriyet. (2007). Bosna'da, terör suçlaması ile biri Türk 4 kişi mahkûm oldu. Erişim Tarihi: 20 Mayls 2019. http://www.hurriyet.com.tr/gundem/bosnada-terorsuclamasi-ile-biri-turk-4-kisi-mahkum-oldu-5754751.

Ignjatijevic, M. (2018). Violent Extremism and Foreign Fighters in Serbia. Returning from violence: How to tackle the foreign fighters' problem in the Western Balkans? Erişim Tarihi; 20 Mayıs 2019. https://kki.hu/hu/projektek/returningfrom-violence-how-to-tackle-the-foreign-fighters-problem-in-the-westernbalkans/returning-from-violence-how-to-tackle-the-foreign-fighters-problem-inthe-western-balkans/11?accessibility $=0$

ISIS Female Returnees Worry The Balkans And Europe / Global Rısk Insigt Erişim Tarihi: 19 Mayis 2019. https://globalriskinsights.com/2018/07/isis-femalereturnees-worry-balkans-europe/.

Keskin Nişancı Alarmı! Sırbistan'da Harekete Geçti. Erişim Tarihi: 15 Mayıs 2019. https://www.haberturk.com/gundem/haber/1189211-cizrede-yakalanan-sirpkeskin-nisanci-sonrasi-alarm.

Koleka, B. (2016). Albanian court jails nine for recruiting fighters for Syria. Erişim Tarihi; 11 Mart 2019. https://www.reuters.com/article/us-mideast-crisis-syriaalbania/albanian-court-jails-nine-for-recruiting-fighters-for-syria-idUSKCNOXU $2 \mathrm{AB}$. 
Kursani, S. (2015). Report inquiring into the causes and consequences of Kosovo citizens' involvement as foreign fighters in Syria and Iraq. Kosovar Center for Security Studies. http://www.qkss.org/repository/docs/Report_inquiring_into_ the_causes_and_consequences_of_Kosovo_citizens'_involvement_as_foreign_fig hters_in_Syria_and_Iraq_307708.pdf

Maksimoviç, Z. Ristic, M. Dragojlo, S. (2016). Jihadists 'Target Young, Marginalised Serbian Muslims’ Balkan Investıgatıve Reporting Network. 38-44.

Maksimovic, Z. Ristic, M. ve Dragojlo, S. (2016). Jihadists 'Target Young, Marginalised Serbian Muslims’ Balkan Investıgatıve Reporting Network. 38-45.

Malet, D. (2013). Foreign Fighters: Transnational Identity in Civil Conflicts. New York: Oxford University Press.

Marusic, S. (2016). Ethnic Tensions Complicate CounterExtremism in Macedonia. Balkan Investıgatıve Reporting Network. 25-31.

Milton, D. ve Price, B. ve Ubaydi, M. (2014). The Islamic State in Iraq and the Levant: More than Just a June Surprise, CTC Sentınel, 7(6).

Nabolli, E. ve Haxhiaj, S. (2018). Parents Of Albanian ISIS Martyrs Abandoned To $\begin{array}{lllll}\text { Grief. } & \text { Erişim } & \text { Tarihi: } & 18 & \text { Mayıs }\end{array}$ https://balkaninsight.com/2018/01/15/parents-of-albanian-isis-martyrsabandoned-to-grief-01-12-2018/

Neumann, P. R. (2015). Foreign Fighter Total in Syria/Iraq Now Exceeds 20.000; surpasses Afghanistan Conflict in The 1980s. Erişim Tarihi; 3 Mart 2019. https://icsr.info/2015/01/26/foreign-fighter-total-syriairaq-now-exceeds-20000surpasses-afghanistan-conflict-1980s/.

Pajaziti, N. (2016). Skopje Court Sentences A Group For Recruitment And Partipication İn The War İn Syria. Erişim Tarihi: 20 Mart 2019. https://balkaneu.com/skopje-court-sentences-group-recruitment-participationwar-syria/

Parents Of Albanian ISIS 'Martyrs' Abandoned To Grıef. (2018). Erişim Tarihi: 5 Mart 2019. https://balkaninsight.com/2018/01/15/parents-of-albanian-isismartyrs-abandoned-to-grief-01-12-2018/. 
Qafmolla, E. (2016). Offer Kosovar Fighters "Jihadi Rehab" to Combat Extremism. Balkan Invest1gatıve Reporting Network. 18-24.

Ragab, E. (2018). Returning Foreign Terrorists: What Type of Security Challenges Are They Posing? Mediterranean Yearbook. 87-93.

Saymaz, İ. (2017). Türkiye'de IŞİD. İstanbul: İletişim Yayıncılık.

Shtuni, A. (2015). Ethnic Albanian Foreign Fighters in Iraq and Syria. CTC Sentınel. $8(4)$.

Sondakika.com, (2007). ABD'nin Viyana Büyükelçiliği'ne saldırı girişiminde bulunan iki kişi yakaland. Erişim Tarihi: 10 Mart 2019. https://www.sondakika.com/haber/haber-abd-nin-viyana-buyukelciligi-ne-saldiri/.

Spahiu, E. (2018, Mayıs 18). Returning IS Fighters İn The Balkans: Beyond The Immediate Securit Threat. Erişim Tarihi: 12 Mart 2019. https://jamestown.org/program/returning-is-fighters-in-the-balkans-beyond-theimmediate-security-threat/.

Speckhard, A. ve Shajkovci, A. (2018). The Balkan Jihad: Recruitment to Violent Extremism and Issues Facing Returning Foreign Fighters in Kosovo and Southern Serbia. Soundings: An Interdisciplinary Journal. 101(2). Ss.79-109.

Sputnik. (2017). 300'den Fazla Kosova'lı Arnavut IŞiD Saflarında Savaşıyor. Erişim Tarihi: 11 Mart 2019. https://tr.sputniknews.com/avrupa/ 201703131027615659-kosovali-arnavutlar-isid-saflarinda-savasiyor/.

Sutarov, V. (2017). The Threat Posed by Foreign Terrorist Fighters to the Republic of Macedonia and the Western Balkans. Atlantic Intitive. 103-124.

Sutarov, V. (2018). Countering Violent Extremism In The Western Balkans. 169181. Erişim Tarihi: 10 Mayıs 2019. file://C:/Users/Lenovo/Downloads/ COUNTERING_VIOLENT_EXTREMISM_IN_THE_WEST.pdf

Tomovic, D. (2016). Montenegro Security Services on ISIS Alert. Balkan Investıgatıve Reporting Network. 32-37.

Yalçınkaya, H. (2017). Işid'in Yabancı Savaşçıları ve Yarattı̆̆ Tehdit: Türkiye'nin Tecrübesi (2014-2016). Uluslararası İlişkiler Dergisi, 14(53), 23-43. 
Yargıtay, terör örgütü DEAŞ'in Niğde saldırısında kararını verdi. (2018). Erişim Tarihi: 18 May1s 2019. https://www.haberturk.com/yargitay-teror-orgutu-deas-innigde-saldirisinda-kararini-verdi-1887903 